\title{
Cytomegalic inclusion disease in the adult
}

\author{
D. J. EVANS ${ }^{1}$ AND E. D. WILliAMS \\ From the Departments of Pathology, London Hospital, \\ and Royal Postgraduate Medical School, London
}

SYNOPSIS The distribution of infected cells in 13 necropsies on adults with cytomegalovirus disease is reported and discussed in relation to the local damage caused by the infection and predisposing factors.

The distribution, with lung as the most common site, but other organs such as thyroid, liver, and colon not infrequently involved, agrees fairly well with other series. No heavy infection confined to one organ was found, and it is concluded that a truly localized infection in the adult probably does not occur.

Evidence of destructive inflammatory changes attributable to the virus was scanty; a lymphocyte and plasma cell infiltrate was sometimes found, and microglial nodules were found in a case with inclusions in the brain. In one case heavy cytomegalovirus infection in the colon was associated with, and probably caused, marked colonic ulceration which led to the death of the patient.

The major predisposing factor to infection in this series was corticosteroid therapy: eight of the 13 patients had been treated with steroids and one had Cushing's syndrome associated with a bronchial carcinoma. Three of the other four patients had a very few inclusions only. Adrenal involvement was not found in any of the steroid-treated patients but was present in two of the four patients not treated with steroids where adrenal sections were available.

It is concluded that most adult patients with cytomegalovirus infection have impaired immune mechanisms, and that heavy infection may rarely lead to a clinically serious disease.

In infants and children cytomegalovirus infection is a common necropsy finding. Seifert and Oehme (1957) found an incidence of 10 to $15 \%$ of infection localized to the salivary gland and of 1 to $3 \%$ of the generalized disease in a review of some 1,700 necropsies of children from various parts of the world. The severe generalized infections which are often fatal occur most often in young infants and in them are probably acquired transplacentally (Medearis, 1957).

Infection of the adult has been found less often in histological material. In 1960 Symmers could find only 29 cases in the literature though the number of reported cases now approaches 100 .

We wish to report 13 necropsy cases and to discuss the factors influencing the extent and significance of the infection.

\section{MATERIALS AND METHODS}

The study was of patients aged 14 or over. Ten cases

${ }^{1}$ Present address: Department of Pathology, Royal Postgraduate Medical School, Ducane Road, London, W.12.

Received for publication 28 September 1967. were from recent routine material. Cases 1 and 2 were found among 18 cases of systemic lupus erythematosus and case 5 was found among 100 leukaemic patients.

All sections were carefully scanned by both of us. The recognition of cytomegalovirus was based on the finding of the classical homogeneous intranuclear inclusion with surrounding halo. Transitional forms with enlarged nuclei and cell bodies but without the nuclear inclusion (Hartz and van der Stadt, 1943) were occasionally seen. Representative sections were stained with Sudan black, Alcian green, Hales iron, mucicarmine, periodic-acid Schiff (PAS) with and without diastase, and Feulgen techniques.

\section{RESULTS}

Clinical data, therapy, and major necropsy findings are shown in Table $I$ and the distribution of inclusions in Table II, endothelial inclusions (which were widespread) being indicated separately. In liver all other inclusions were in parenchymal cells except for one in a bile duct (case 7). Pancreatic acinar involvement (cases 1 and 4) and islet involvement (case 8) were seen. Kidney tubules were affected in cases 7, 8, and 11 (Fig. 1). Most of the lung 
TABLE I

SUMMARY OF CLINICAL, THERAPEUTIC, AND NECROPSY DETAILS ON 13 ADULT CASES OF CYTOMEGALOVIRUS INFECTION

\begin{tabular}{|c|c|c|c|c|}
\hline $\begin{array}{l}\text { Case } \\
\text { Year }\end{array}$ & $\begin{array}{l}\text { Age } \\
\text { Sex }\end{array}$ & Clinical Details & Therapy & Necropsy Findings \\
\hline $\begin{array}{l}1 \\
(1927)\end{array}$ & $30 \mathrm{~F}$ & $\begin{array}{l}12 \text { yr discoid lupus erythematosus; } 4 \text { yr } \\
\text { Raynaud's phenomena, } 2 \text { weeks' diarrhoea }\end{array}$ & $\begin{array}{l}\text { Neoarsphenamine, } \\
\text { sodium } \\
\text { aurothiosulfate }\end{array}$ & $\begin{array}{l}\text { Sinuous mucosal ulcers in caecum, periarter- } \\
\text { ial 'onion skins' in spleen, } \mathbf{R} \text { apical tuber- } \\
\text { culosis }\end{array}$ \\
\hline $\begin{array}{l}2 \\
(1957)\end{array}$ & $28 \mathrm{~F}$ & $\begin{array}{l}6 \text { yr disseminated lupus erythematosus } \\
\text { (mouth ulcers, rash, arthritis), terminal } \\
\text { pyopneumothorax }\end{array}$ & $\begin{array}{l}\text { Cortisone } 800 \mathrm{mg} / \\
\text { day, aureomycin }\end{array}$ & $\begin{array}{l}\text { Periarterial 'onion skins' in spleen, right } \\
\text { pyopneumothorax }\end{array}$ \\
\hline $\begin{array}{l}4 \\
(1962)\end{array}$ & $61 \mathrm{~F}$ & $\begin{array}{l}\text { Few weeks pemphigus vulgaris. steroid- } \\
\text { induced diabetes. terminal necrotic skin } \\
\text { and subcutaneous lesions }\end{array}$ & $\begin{array}{l}\text { Prednisone } \\
100 \mathrm{mg} / \text { day }\end{array}$ & $\begin{array}{l}\text { Non-specific necrotic skin lesions, occult } \\
\text { papillary thyroid carcinoma }\end{array}$ \\
\hline $\begin{array}{l}5 \\
(1960)\end{array}$ & $16 \mathrm{M}$ & 9 months acute blastic leukaemia & $\begin{array}{l}\text { Prednisone } \\
100 \mathrm{mg} / \text { day }\end{array}$ & Leukaemia \\
\hline $\begin{array}{l}6 \\
(1964)\end{array}$ & $61 \mathrm{M}$ & $\begin{array}{l}3 \text { months Cushing's syndrome (hyper- } \\
\text { pigmentation, hyperglycaemia ( } 17 \text {-oxogenic } \\
\text { steroids } 51 \mathrm{mg} / 24 \mathrm{hr} \text { ). Bronchial carcinoma. } \\
\text { Died postoperatively }\end{array}$ & & $\begin{array}{l}\text { Asbestosis, widespread secondary oat cell } \\
\text { carcinoma, adrenal hyperplasia and } \mathbf{R} \text { adrena } \\
\text { vein thrombosis, gastric ulcer, Aspergillus } \\
\text { abscess in lung }\end{array}$ \\
\hline $\begin{array}{c}7 \\
(1962)\end{array}$ & $42 \mathrm{~F}$ & $\begin{array}{l}\text { Pelvic tuberculosis (treated operatively). } \\
2 \text { months therapy with PAS, INAH. Liver } \\
\text { failure. Septicaemia from infected I.V.C. } \\
\text { cannula }\end{array}$ & $\begin{array}{l}\text { Cortisone } \\
\text { ? dose }\end{array}$ & $\begin{array}{l}\text { Acute bacterial endocarditis, focal hepatic } \\
\text { haemorrhagic areas, malignant lymphoma } \\
\text { with marked eryth rophago-cytosis? } \\
\text { histocytic medullary reticulosis }\end{array}$ \\
\hline $\begin{array}{l}8 \\
(1959)\end{array}$ & $58 \mathrm{M}$ & $\begin{array}{l}\text { See Heard et al. (1962). Longstanding } \\
\text { diabetes. Renal failure }\end{array}$ & $\begin{array}{l}\text { Prednisone } \\
60 \mathrm{mg} / \text { day }\end{array}$ & $\begin{array}{l}\text { Diabetic glomerulo-sclerosis, } \mathbf{R} \text { adrenal } \\
\text { adenoma, aspergillus in lung infarct }\end{array}$ \\
\hline $\begin{array}{l}9 \\
(1963)\end{array}$ & $17 \mathrm{~F}$ & $\begin{array}{l}\text { See Dempster et al. (1964). Renal failure } \\
\text { following chronic pyelonephritis; renal } \\
\text { transplant }\end{array}$ & $\begin{array}{l}\text { Hydrocortisone } \\
100 \mathrm{mg} / \text { day, } \\
\text { local } x \text { rays }\end{array}$ & $\begin{array}{l}\text { Chronic pyelonephritis, infarcted renal } \\
\text { transplant }\end{array}$ \\
\hline $\begin{array}{l}10 \\
(1965)\end{array}$ & $50 \mathrm{M}$ & $\begin{array}{l}\text { Polycystic kidneys; renal failure treated } \\
\text { by renal transplant }\end{array}$ & $\begin{array}{l}\text { Prednisone } 100 \mathrm{mg} / \\
\text { day, Imuran } 200 \mathrm{mg} / \\
\text { day }\end{array}$ & $\begin{array}{l}\text { Polycystic liver and kidneys, small old } \\
\text { cerebral infarct, tubular necrosis of renal } \\
\text { transplant }\end{array}$ \\
\hline $\begin{array}{l}11 \\
(1964)\end{array}$ & $56 \mathrm{~F}$ & $\begin{array}{l}1 \text { yr malignant hypertension with renal } \\
\text { failure; urinary infections }\end{array}$ & & $\begin{array}{l}\mathbf{R} \text { apical fibrocaseous tuberculosis, bilateral } \\
\text { chronic pyelonephritis }\end{array}$ \\
\hline $\begin{array}{l}12 \\
(1963)\end{array}$ & $59 \mathrm{~F}$ & $\begin{array}{l}6 \text { yr diabetes mellitus, } 11 \text { months heart } \\
\text { failure after cardiac infarction, } 1 \text { week } \\
\text { hemiparesis }\end{array}$ & $\begin{array}{l}\text { No steroids, blood } \\
\text { transfusions, or } \\
\text { cytotoxic drugs }\end{array}$ & $\begin{array}{l}\text { Extensive old myocardial infarct } \mathbf{R} \text { cere- } \\
\text { bellar, and } \mathbf{R} \text { internal capsule softenings, } \\
\text { splenic infarcts }\end{array}$ \\
\hline $\begin{array}{l}13 \\
(1963)\end{array}$ & $84 \mathrm{~F}$ & $\begin{array}{l}10 \text { yr myxoedema, } 3 \text { yr papillary } \\
\text { carcinoma of bladder (partial cystectomy), } \\
\text { terminal hypothermia }\end{array}$ & & $\begin{array}{l}\text { Invasive squamous carcinoma of bladder, } \\
\text { focal 'adrenalitis', classical myxoedema of } \\
\text { thyroid }\end{array}$ \\
\hline
\end{tabular}

TABLE II

DISTRIBUTION OF INCLUSIONS IN 13 CASES OF ADULT CYTOMEGALIRUS INFECTION ${ }^{1}$

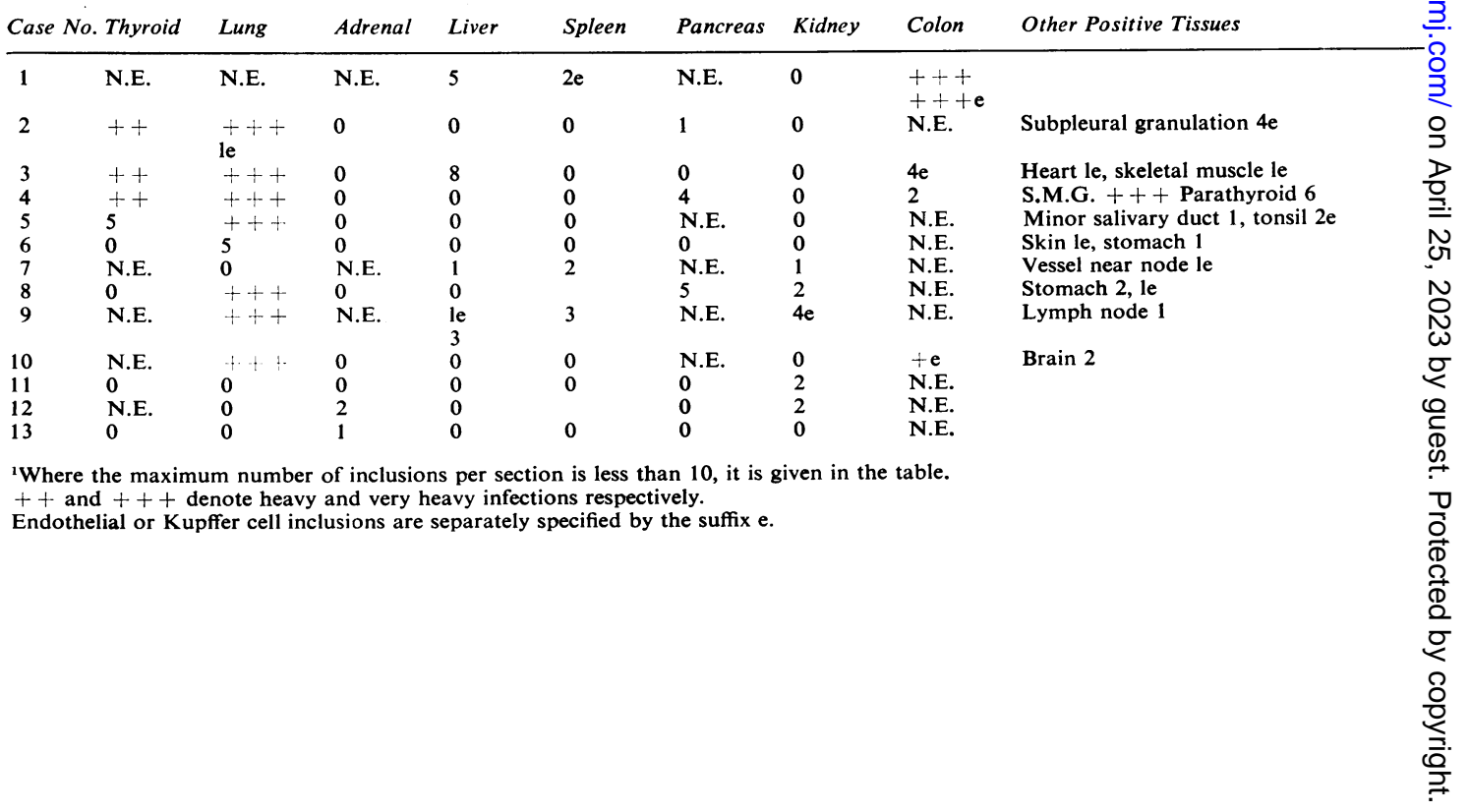


inclusions were in alveolar lining cells or macrophages but were frequent in an area of bronchiolar metaplasia in case 5 and in bronchial epithelium in case 10. Rare gastric epithelial inclusions were seen.

In case 10 inclusions were present in brain in unidentifiable cells. One of them was related to a microglial nodule (Fig. 2) and several other microglial nodules were seen. The adrenal inclusions (cases 12 and 13 ) were probably cortical. All were related to foci of lymphocytes and plasma cells, though in case 13 focal adrenalitis was widespread. Inclusions in submandibular gland (case 4) were in acini and ducts. A moderate chronic inflammatory infiltrate was present in affected lobules (Fig. 3). The colon in case 1 showed a heavy cytomegalovirus infection involving endothelium, epithelium, and muscularis mucosae. Ulcerative lesions and local inflammation were present, but no crypt abscesses were seen. The restriction of lesions to the right side of the colon and the histology were against ulcerative colitis or gold-induced ulceration and were consistent with cytomegalovirus-induced ulceration.

Cytoplasmic inclusions were unpredictable in their occurrence: they were seen in endothelial cells (Fig. 4) as well as in epithelial cells and in both they showed identical histochemical staining, giving a positive reaction with diastase periodicacid Schiff, Hales dialysed iron, mucicarmine, and Alcian green. Although the granules have been shown to contain virus (Martin and Kurtz, 1966) they did not give a positive reaction with the Feulgen technique.

\section{DISCUSSION}

Cytomegalovirus in the adult is usually an unexpected finding in necropsy or surgical material, though the virus can be grown in tissue culture and increasing numbers of cases are being diagnosed in life (eg Jacox, Mongan, Hanshaw, and Leddy, 1964).

Antibody studies have shown that the infection is common, and in a survey of adults in Greater London in 1965 Stern and Elek found that $54 \%$ of people between 25 and 35 years old had antibodies. The infection is a long lasting one; excretion of virus in the urine may persist for up to 10 months post partum in women delivered of infected foetuses (Medearis, 1964) and Stern (1965) has obtained repeatedly positive throat swabs over a period of years from apparently healthy adults.

Since it is a common infection and long lasting, its rarity in postmortem material is at first sight surprising. This is probably due in part to the fact that infection is commonest in the 15-35 age group which forms only a small proportion of most

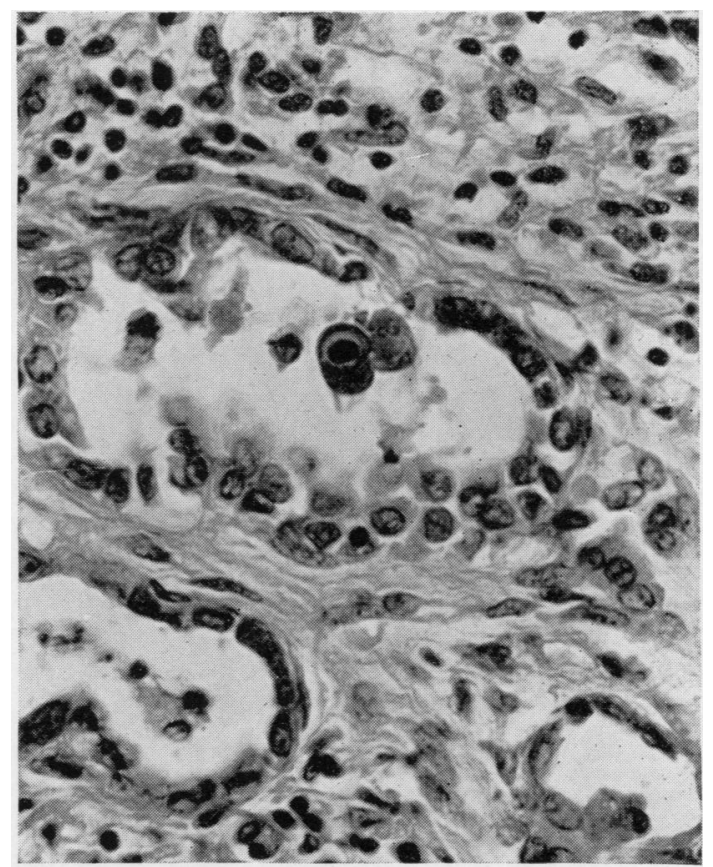

FIG. 1. Renal tubule containing in its lumen two infected cells, one classical, the other tangentially cut in case 11. Haematoxylin and eosin $(\times 325)$.

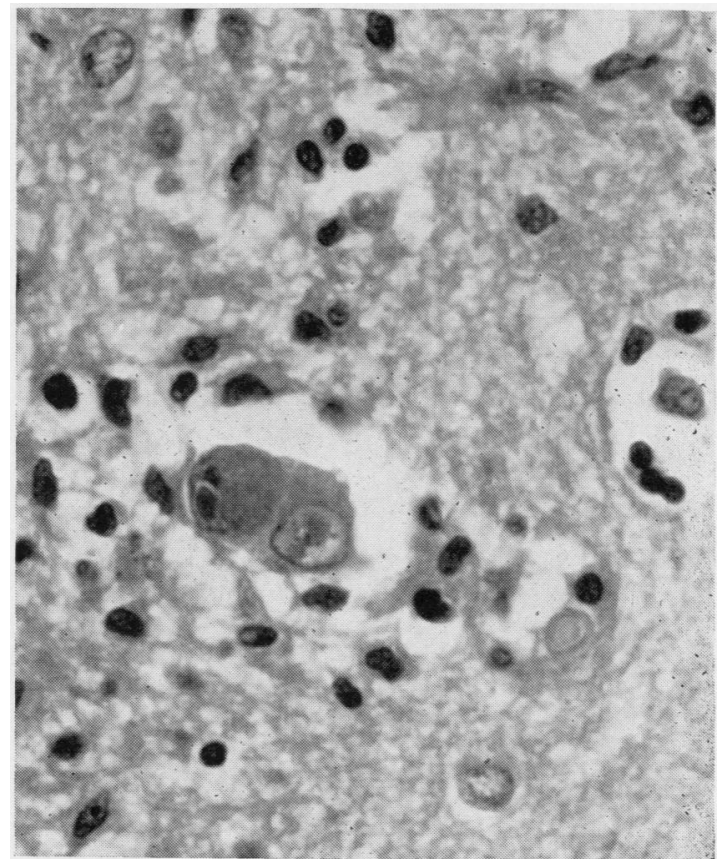

FIG. 2. Brain. The centre of the field shows one definite and one possible inclusion-bearing cell with a surrounding microglial reaction, in case 10. Haematoxylin and $\operatorname{eosin}(\times 64)$. 


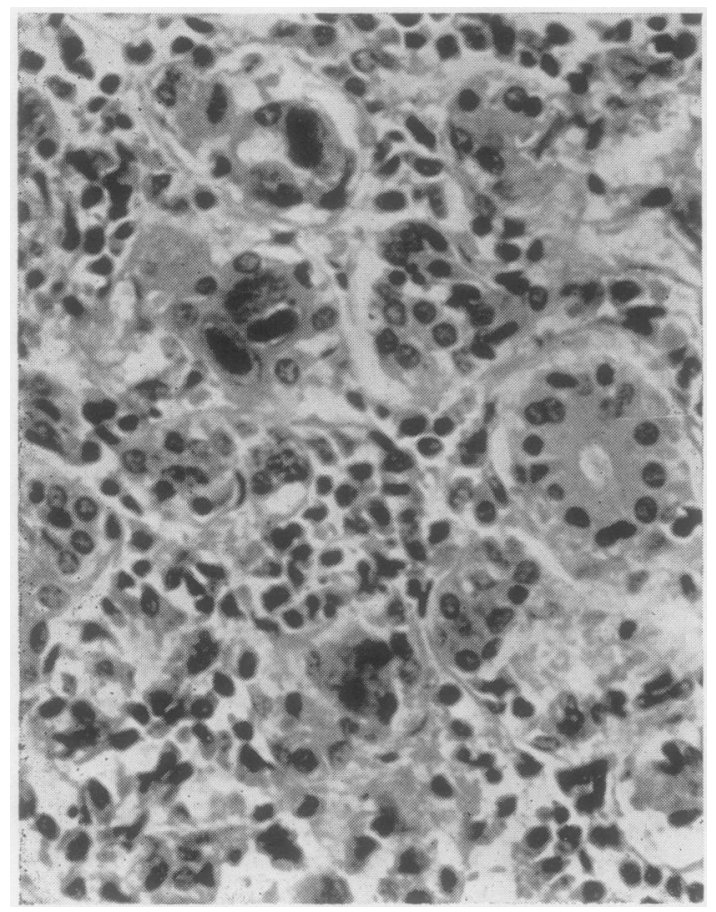

FIG. 3. Submandibular salivary gland. Several affected cells, one with obvious cytoplasmic inclusions. There is an interstitial lymphocytic and plasma cell infiltrate. Case 4. Haematoxylin and eosin $(\times 325)$.

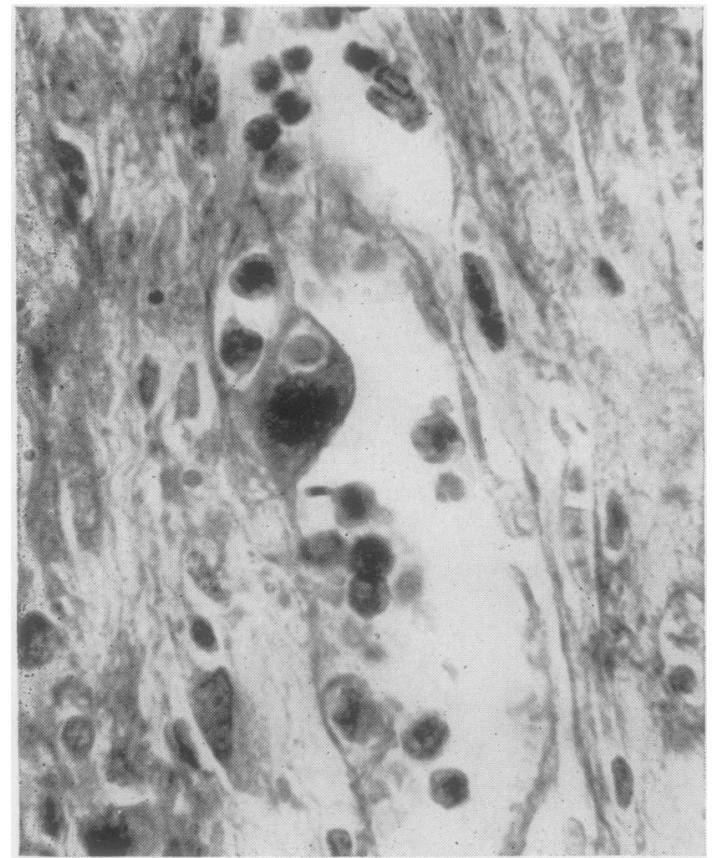

FIG. 4. Colon. An infected endothelial cell from submucosa. Aggregated PAS-positive cytoplasmic inclusions are present. Case 1. PAS $(\times 850)$. necropsy series ( $5 \%$ of our own in 1959-63). Another
factor may be the difficulty in finding cytopathic changes even when an infection is present. Hanshaw (1964) obtained a positive culture from a liver where inclusions were very sparse. This was an active not a latent infection since cultures from many organs of control necropsies were negative. Our case 11 is comparable. A single inclusion was found in one of three sections and two further inclusions in three levels of the same block.

It has been customary to divide infections in the $\overrightarrow{\vec{A}}$ adult into a localized and a generalized form. The $\vec{\omega}$ recognition of a localized disease was based partly on surgical material from patients with diseases unrelated to the cytomegalovirus and partly on $\stackrel{-}{-}$ necropsies. An extreme diversity of 'localized' $\omega$ sites has been reported in surgical material ranging $\stackrel{\omega}{\vec{\omega}}$ from salivary glands to cervix uteri and inflammatory lesions in the nose to inflammatory lesions of the anal canal ${ }^{1}$. Since other tissues have not been $\vec{z}$ examined, evidence of localization in these cases is not adequate. In the necropsy material many of the $\overrightarrow{\vec{\theta}}$ reports do not say that a careful search was made $\mathscr{\odot}$ for inclusions outside the obviously affected organ but excluding these, cases with infection localized to gut, adrenal, liver, and lung have been reported ${ }^{\mathbf{1}}$. Three of our cases had inclusions in only one organ (kidney or adrenal) but the number of inclusions in each case was small. It does not seem as if any $\stackrel{\mathbb{Q}}{\complement}$ organ in the adult is especially liable to 'localized' $\overrightarrow{\overrightarrow{0}}$ infection and it may well be that all such cases have $\frac{3}{3}$ a light generalized infection.

The heavy generalized infection seen in the adult is often associated with conditions in which immunological responses are impaired, eg, Hodgkin's? disease, therapy with steroids or cytotoxic drugs. It 3 has been regarded by some as a reactivation of a latent infection and by others as fortuitous infection $\frac{0}{3}$ (Bodey, Wertlake, Douglas, and Levin, 1966). Two of our cases had recognized causes of immune paresis (leukaemia and lymphoma) but corti- $\frac{\vec{O}}{0}$ costeroids appear to be the factor of major importance in our series. Eight of the 10 patients with $N$ disseminated disease had received corticosteroids $N$ therapeutically, and one other had Cushing's $N$ disease associated with bronchial carcinoma. Steroids $\omega$ suppress primary antibody response and delayed? hypersensitivity reactions. Virus infections are rarely troublesome in cases with hypogammaglobulinae- $\mathbb{D}$ mia, suggesting that delayed hypersensitivity may ${ }^{+}$ be important in dealing with viruses. However, $\frac{T}{\circ}$ experimentally antibodies may restrict the growth of virus in culture to a plaque though permitting $\stackrel{?}{+}$ limited cell to cell spread (Wheeler and Canby, 1959). $\stackrel{\mathbb{\Omega}}{\Omega}$ The close relationship of infected cells in some of ${ }^{1}$ Details and references are available on request. 


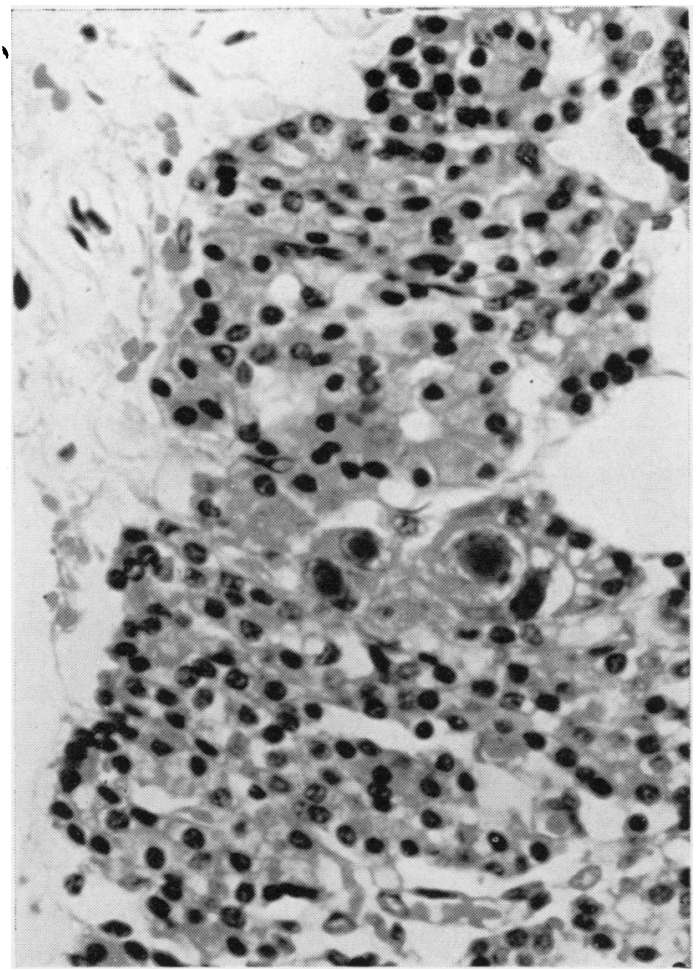

FIG. 5 .

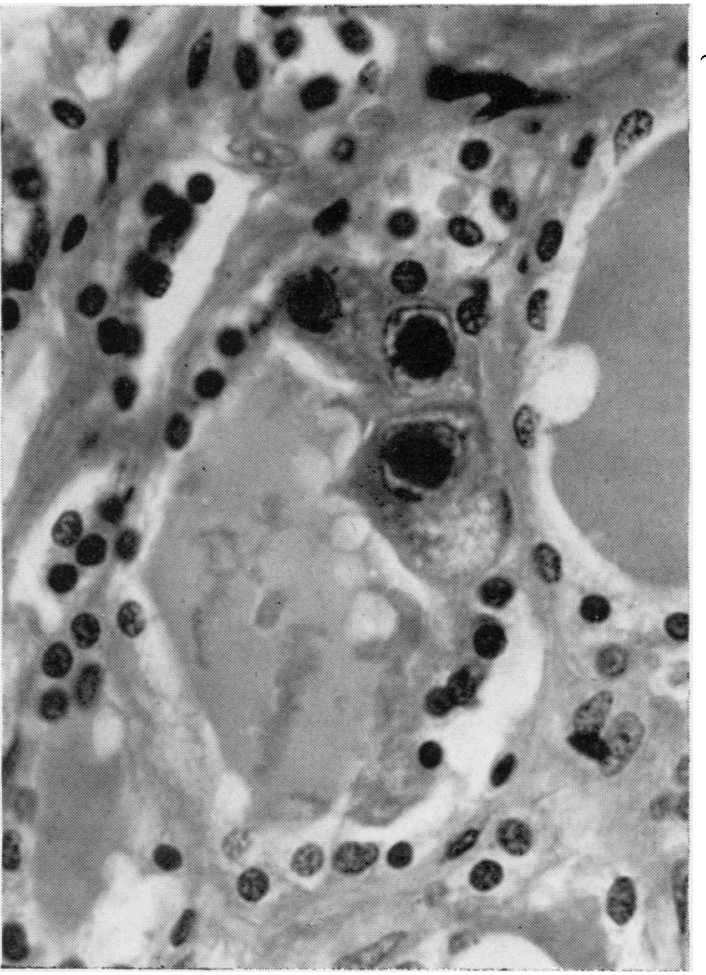

FIG. 6.

FIG. 5. Infected cells in parathyroid in case 4. Haematoxylin and eosin $(\times 325)$.

FIG. 6. Thyroid showing three adjacent cells with intranuclear inclusions in case 4. Haematoxylin and eosin (640).

our cases (Figs. 5, 6) suggests that cell to cell transfer of cytomegalovirus may occur, a mechanism which could account for persistence of infection in one or several organs after cessation of viraemia. Failure of antibody response might be responsible for unrestricted spread of cytomegalovirus.

The distribution of inclusions in our generalized cases (Table II) is similar to that observed by others (Table III), the lung being the most heavily infected organ in eight out of nine cases where it was available. The most striking difference is the low incidence of adrenal involvement in our cases. Neither of our two cases with adrenocortical cytomegalovirus had received steroid therapy while no patient receiving steroids showed adrenal involvement. This suggests that the suppressed adrenal cortex may be less vulnerable to infection. A study of reported cases does not show a clear difference in adrenal involvement between steroid-treated and untreated groups, although in some reports 'steroid therapy' may include ACTH treatment.

The extent to which cytomegalovirus produces illness in the adult is still debatable. Lamb and Stern
TABLE III

FREQUENCY OF HISTOLOGICAL INVOLVEMENT OF ORGANS IN PUBLISHED NECROPSY STUDIES OF DISSEMINATED CYTOMEGALOVIRUS INFECTIONS IN THE ADULT ${ }^{1}$

\begin{tabular}{lrrr} 
& Positive & Negative & Not S \\
\hline Lung & 42 & 1 & 0 \\
Liver & 18 & 11 & 14 \\
Adrenal & 25 & 3 & 15 \\
Stomach & 7 & 2 & 34 \\
Spleen & 14 & 9 & 20 \\
Small intestine & 11 & 4 & 28 \\
Pancreas & 14 & 7 & 22 \\
Kidney & 14 & 11 & 18 \\
Esophagus & 6 & 1 & 36 \\
Colon & 7 & 5 & 31 \\
Lymph node & 10 & 4 & 29
\end{tabular}

${ }^{1}$ Data from Wong and Warner (1962), with the addition of the following: Kawachi (1958); Chiari (1960); Bunarevic and Urbanke (1961); Signer (1962); Cazal et al.; Scattini et al., (1963); Becker and Eddy; Hanshaw (1964); Rifkind (1965); Hedley-Whyte and Craighead; Nakamura et al. (1965); Rose; Kanich and Craighead; Duvall et al. (1966).

(1966) have suggested that it may cause jaundice. It has also been proposed as the agent causing a glandular fever syndrone after open heart surgery or after the transfusion of fresh blood (Kääriäinen, 
Klemola, and Paloheimo, 1966). The organism causes death of cells which may be desquamated (eg, into thyroid colloid or into urine). Its ability to produce ulceration in epithelium or an inflammatory response may depend on the heaviness of the local infection. Inflammatory responses have been described in many sites-lung, adrenal, heart, brainand twe cases are recorded in which an ulcerative colitis-like syndrome was associated with a heavy colonic infection ${ }^{1}$. None of our cases had pneumonitis, and the chronic inflammatory lesions in adrenals (cases 12,13), salivary glands (case 5), and the microglial nodules in the brain (case 10) were not associated with clinical symptoms or signs. In case 1 , however, an ulcerative-colitis-like syndrome with severe diarrhoea was present, and the infection may have contributed to death.

It seems fair to conclude that in the adult cytomegalovirus infection is rarely of serious significance, only occasionally contributing to the death of an otherwise ill patient. Its numerical importance as a cause of foetal disease is not yet adequately assessed but it seems likely that (as with rubella) transplacental infection of the foetus is the most important consequence of adult infection.

We wish to thank Professors C. V. Harrison and F. E. Camps and Dr. B. E. Heard for permission to publish their cases, Professor J. G. Azzopardi and Dr. H. Urich for helpful advice, Messrs R. Hammond and W. Brackenbury for the photomicrographs, and Misses R. L. Creswell and S. V. Hearne for secretarial assistance.
REFERENCES

Becker, F. P., and Eddy, J. R. (1964). New York med. J., 64, 1211. Bodey, G. P., Wertlake, P. T., Douglas, G., and Levin, R. H. (1965). Ann. intern. Med., 62, 899.

Bunarevic, A., and Urbanke, A. (1961). Acta med. iugosl., 15, 227. Cazal, P., Mirouze, J., Pages, A., Jaffiol, C., and Ginier, C. (1963). Sem. Hop. Paris, 39, 1294.

Chiari, H. (1960). Wien. klin. Wshr., 72, 383.

Dempster, W. J., Harrison, C. V., and Shackman, R. (1964). Brit. med. J., 2, 969.

Duvall, C. P., Casazza, A. R., Grimley, P. M., Carboner, P. P., and Rowe, W. P. (1966). Ann. intern. Med., 64, 531.

Hanshaw, J. B. (1964). Post grad. Med., 35, 472.

Hartz, P. H., and van de Stadt, F. R. (1943). Amer. J. clin. Path., 13, 148.

Heard, B. E., Hassan, A. M., and Wilson, S. M. (1962). J. clin. Path. $15,17$.

Hedley-Whyte, E. T., and Craighead, J. E. (1965). New Engl. J. Med., 272, 473.

Jacox, R. F., Mongan, E. S., Hanshaw, J. B., and Leddy, J. P. (1964). Ibid., 271, 1091 .

Käăriäinen, L., Klemola, E., and Paloheimo, J. (1966). Brit. med. J., $1,1270$.

Kanich, R. E., and Craighead, J. E. (1966). Amer. J. Med., 40, 874.

Kawachi, S. (1958). Nippon Byori Gakkai Kaishi, 3, 381.

Lamb, S. G., and Stern, H. (1966). Lancet, 2, 1003.

Martin, A. M., Jr., and Kurtz, S. M. (1966). Arch. Path., 82, 27.

Medearis D. N., Jr. (1957). Pediatrics, 19, 467.

(1964). Bull Johns Hopk. Hosp., 114, 181.

Nakamura, R. M., Kimura, K., and Ichimura, M. (1965). Acta path. jap., 14, 45.

Rifkind, D. (1965). Arch. intern. Med., 116, 554.

Rose, M. S. (1966). J. clin. Path., 19, 266.

Scattini, C. M., Campos, C. A., and Bur, G. E. (1963). Pren. med. argent., $50,1217$.

Seifert, G., and Oehme, J. (1957). Pathologie und Klinik der Cytomegalie. Thieme, Liepzig.

Signer, E. (1962). Path. et Microbiol. (Basel), 25, 359.

Stern, H. (1965). Proc. roy. Soc. Med., 58, 346.

—, and Elek, S. D. (1965). J. Hyg. (Lond.), 63, 79.

Symmers, W. St. C. (1960). J. clin. Path., 13, 1.

Wheeler, C. E., and Canby, C. M. (1959). Arch. Derm., 79, 86.

Wong, T. W., and Warner, N. E. (1962). Arch. Path., 74, 403. 